PROCEEDINGS OF THE UNITED STATES NATIONAL MUSEUM

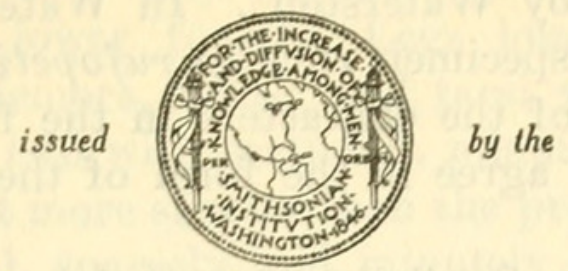

SMITHSONIAN INSTITUTION

U. S. NATIONAL MUSEUM

\begin{tabular}{lll}
\hline Vol, 92 & Washington : 1942 & No. 3150
\end{tabular}

\title{
THE GENO'TYPES OF SOME OF ASHMEAD'S GENERA OF ICHNEUMON-FLIES
}

\author{
By R. A. Cushman
}

IN THE keys to his Classification of the Ichneumon Flies, Ashmead ${ }^{1}$ proposed 21 genera with so-called manuscript species designated as genotypes. That is, these genera and their genotypes were described only by the key characters leading to the genera. Some of these have since been more fully described by Ashmead or by other authors, but several are still in their original status. One genus, ostensibly of this sort, was described by Ashmead prior to 1900.

In the following pages I shall indicate the relationships of these genera and redescribe the genotypes that have not already been redescribed.

\section{Genus ZONOCRYPTUS Ashmead}

Zonocryptus Ashmead, Proc. U. S. Nat. Mus., vol. 23, p. 40, 1900. (Genotype, "Cryptus sphingis Ashmead, manuscript," monobasic.)

The genotype was said to be from Africa. The only specimen in the collection in the United States National Museum that fulfills all the requirements of character and habitat is a male labeled "Ex sphinx chrysalis from Central Africa, I. Helen Moffat (Denton)" and bearing the name label "Cryptus formosus Br." in Ashmead's handwriting. There can, I think, be no doubt that the genus Zonocryptus was based on this specimen.

1 Proc. U. S. Nat. Mus., vol. 23, pp. 1-220, 1900. 
As thus typified, Zonocryptus falls within the limits of Oneilella Cameron as treated by Waterston ${ }^{2}$. In Waterston's key to males the above-mentioned specimen runs to rufopetiolata Waterston, but disagrees with most of the characters in the formal description of that species. It does agree in the form of the areolet as described in the key to females.

It seems likely that Oneilella as treated by Waterston is a composite genus, a possibility suggested by Waterston himself. If such proves to be the case, Zonocryptus would include those species in which the sides of the areolet converge toward the radius with the first intercubitus much more oblique than the second. Too little material of the group is before me to justify the synonymizing of Oncilella with Zonocryptus or the transferring of any species from the one to the other.

\section{ZONOCRYPTUS SPHINGIS (Ashmead)}

\section{Male--Length $14 \mathrm{~mm}$.}

Head polished, impunctate except finely and sparsely so on face; temples strongly convex, nearly as broad as eyes anteriorly; inner margins of eyes convexly curved, frons broadening dorsally and face ventrally; frons deeply concave, but not carinately bordered laterally; face slightly elevated medially; clypeus strongly convex in middle, its apical slope steep and with a blunt tooth; malar space three-fourths as long as basal width of mandible; mandible twice as broad at base as at apex, finely and irregularly rugulose, upper tooth longer and more acute than lower tooth; second joint of maxillary palpus broad and nearly parallel-sided; with a rounded protuberance on apical exterior angle; antenna (both broken) with first joint of flagellum nearly a half longer than second joint, others gradually diminishing in length, subapical joints transverse.

Thorax punctato-rugose laterally, polished and virtually impunctate dorsally; mesoscutum with a low, median, triangular elevation anteriorly, notaulices fine and shallow; scutellum sloping nearly from base, subacute at apex, fovea deep and bounded laterally by very high carinae; propodeum coarsely reticulate-punctate, basally nearly smooth, and apical slope irregularly rugose, spiracles elongate oval; pronotum smooth above, obliquely striate in scrobe; speculum polished, prepectoral carina incomplete above, sternaulices short and broad. Wings broad; stigma narrow with radius basad of middle; basal vein straight; ramellus very short, the two abscissae of discocubitus straight; areolet small, pentagonal, higher than long, intercubiti strongly convergent, the first much more strongly oblique than

${ }^{2}$ Bull. Ent. Res., vol. 18, pp. 191-204, 1927. 
second; nervulus postfurcal, the vein between it and basal very strongly oblique; abscissula and intercubitella equal in length; nervellus sharply broken at lower fourth. Legs long and slender; coxae sparsely punctate; femora, tibiae, and tarsi with dense, very short pubescence, the last two with scattered, minute spines, tarsi slender, each succeeding joint more slender than the preceding.

Abdomen polished, sparsely and minutely pubescent; postpetiole about a half wider than petiole; second segment equal in length to first; squama of genitalia thick and opaque.

Black; head, mandibles, scape, pedicel, and broad anterior margin of pronotum ferruginous; flagellar joints 10 to 14 pale; wings brownish, front wing with a broad hyaline band extending from base of stigma to about apical third of radial cell and nearly to posterior margin; hind wing hyaline along folds and in middle of brachiellan cell; tergites 5 to 8 white and submembranous apically, 7 and 8 so nearly to bases medially.

Type locality.-Central Africa.

Host.-.Sphinx chrysalis."

Type.-U. S. N. M. No. 56287.

A single male specimen taken by I. Helen Moffat.

\section{Genus METARHYSSA Ashmead}

Metarhyssa Ashmead, Proc. U. S. Nat. Mus., vol. 23, p. 40, 1900. (Genotype, M. bifasciata Ashmead, monobasic.)

The genotype was recorded as from Africa. In the collection in the National Museum are two male specimens from Africa labeled by Ashmead "Opisthorhyssa bifasiata Ashm." that run to Metarhyssa in Ashmead's key. There appears no doubt that these specimens constitute the basis of the description of Metarhyssa, and that Ashmead changed to Metarhyssa to avoid confusion between Opisthorhyssa and Opisorhyssa Kriechbaumer, 1890. It should be noted that in Opisthorhyssa (behind+rugose) Ashmead undoubtedly referred to the same character as in Metarhyssa (between + rugose), that is, the transversely striate "metathorax." The specific name "bifasiata" is an obvious lapsus for bifasciata.

As thus typified, the genus belongs to that group of genera of the Cryptini characterized by truncate clypeus with or without a median tooth, rather long propodeum with at most the basal carina, first tergal spiracles placed at or near the middle, and, in the female, by inflated front tibiae and long seventh and eighth tergites. Other members of this group are Echthrus, Agonocryptus, Torbda, Xoridescopus, etc. 
Male.-Length $14 \mathrm{~mm}$., antenna $14 \mathrm{~mm}$.

Body and legs with long, slender hairs especially on head, thorax, first abdominal segment, and hind coxae.

Head polished, face and frons partly transversely striate; temples short and convexly receding; eyes slightly converging below; clypeus with a few large punctures, truncate, with a median apical tooth; malar space half as long as basal width of mandible; antenna very slender, filiform, with short, stiff, vertical pubescence and sparser, appressed pubescence.

Thorax slender, polished, with scattered, coarse punctures on prescutum, mesopleuron, and metapleuron, the propodeum transversely striate except at base, without carina, spiracles elongate oval; pronotum with a few punctures in humeral angle; notaulices deep and meeting on disk, the lobes very strongly convex; prepectoral carina nearly complete above. Wings: Stigma exceedingly narrow with radius far before middle; areolet small, quadrangular, the intercubiti meeting, first intercubitus more strongly oblique than second; nervulus antefurcal; nervellus broken at lower third, reclivous. Legs very slender.

Abdomen slender; first tergite with hairs erect, spiracles before middle, postpetiole gradually broader than petiole.

Black; inner and lower posterior orbit narrowly whitish; mandibles and clypeus reddish piceous; antenna with a small whitish annulus beyond middle; legs piceous, front and middle tibiae narrowly whitish basally and the front tibia anteriorly, hind tarsus whitish except at extreme base and apex; wings hyaline, with apical fourth, a broad band at about middle of front wing and a corresponding but incomplete band on hind wing brown.

Type locality.-Mt. Coffee, Liberia.

Type.-U.S.N.M. No. 56288.

Two males taken in February 1897 by Rolla P. Currie.

\section{Genus OPISOXESTUS Ashmead}

Opisoxestus Ashmead, Proc. U. S. Nat. Mus., vol. 23, p. 40, 1900. (Genotype, o. ferrugineus Ashmead, monobasic.)

The single female specimen on which this genus was based lacks the head, right hind wing and hind leg, and part of the right front leg. It is a species of Joppidium in which the only sculpture consists of striation and foveolation in the pronotal scrobe and along the sutures and furrows. On the label the generic name is spelled "Opisthoxestus", which makes evident Ashmead's intention to derive the name from $\ddot{o} \pi \iota \sigma \theta \epsilon$ (behind) and $\zeta \epsilon \sigma \tau o ́ s$ (polished) in reference 
to the highly polished propodeum, not as Dalla Torre has interpreted it, ó $\iota \sigma \omega$ (backward) and Xestus (a proper name).

(Opisoxestus Ashmead)=Joppidium Cresson. New synonymy.

JOPPIDIUM FERRUGINEUM (Ashmead), new combination

Opisoxestus ferrugineus AsHMEAD, proc. U. S. Nat. Mus., vol. 23, p. 40, 1900.

Female.-Length (estimated) $14 \mathrm{~mm}$., ovipositor sheath $6.5 \mathrm{~mm}$. Head (missing).

Thorax polished, striate or foveolate in pronotal scrobe and along all sutures and furrows; propodeum with only faint lateral traces of basal carina.

Abdomen polished, finely and densely pubescent.

Ferruginous; wings deep black with purple reflections; front and middle legs concolorous with body, the tarsi darker; hind leg, except coxa, piceous to black; first tergite broadly, others narrowly blackish apically.

Type locality.-Ecuador.

Type.-U.S.N.M. No. 56289.

I have seen only the type.

\section{Genus CRYPTOPTERYX Ashmead}

Cryptopteryx Ashmead, Proc. U. S. Nat. Mus., vol. 23, p. 42, 1900. (Genotype, C. columbianus Ashmead, monobasic.)

This genus was based on a single female in the National collection. Both wings on the right side, the antennae, and most of the tarsi are gone.

Except for the long propodeal apophyses, somewhat prominent clypeus, and only slightly convergent areolet the genus seems to me to be rather closely related to Cryptus. In fact, if at couplet 14 in the key to the Cryptini the clypeus, the form of which is merely an exaggeration of the convexity of the clypeus of Cryptus, be considered as not toothed or angulated, the type will run to Cryptus, agreeing very well with all characters. It also agrees with Cryptus in its concave frons, long epomia, distinct notaulices, complete prepectoral carina, strongly convex scutellum, slender antennae, subbasally swollen femur, long narrow radial cell, and sagittate ovipositor.

\section{CRYPTOPTERYX COLUMBIANUS Ashmead}

Female.-Length $11 \mathrm{~mm}$., ovipositor sheath $2.5 \mathrm{~mm}$.

Body mat and with short, very dense, fine, golden pubescence.

Head strongly transverse, temples flat and strongly receding; occiput and frons rather deeply concave, frons with a median carina; 
eyes large and nearly parallel; clypeus in profile somewhat nasute; malar space nearly as long as basal width of mandible; antenna (of another specimen) very slender filiform, nearly as long as body.

Thorax deeper than broad; epomia reaching nearly to dorsal margin of pronotum, scrobe obliquely striate; scutellum briefly margined basally; mesopleuron, metapleuron, and sides of propodeum obliquely striate, carina between metapleuron and propodeum obliterated; propodeum rugulosely punctate, apically somewhat transversely striate, basal carina sharply angulate toward base medially, apophyses very long, conical. Wings as in Cryptus except that apical abscissa of radius is strongly curved, areolet is weakly convergent, and upper abscissa of nervellus is straight. Legs long, slender, as in Cryptus.

Abdomen slender; first segment slender, without carinae, postpetiole about twice as broad as petiole, latter slender with tergite and sternite confluent.

Ferruginous; head mostly yellow; wings uniformly yellow hyaline; antenna (from another specimen) yellow with apical third black; legs concolorous, with hind tarsus (from another specimen) yellow except base of first joint; ovipositor sheath black.

Type locality.-Colombia.

Type.-U.S.N.M. No. 13190.

The type and only specimen seen by Ashmead bears no other data.

A second female from Bogota is somewhat larger than the type and has the propodeum more distinctly striate posteriorly and a slight indication of the apical carina medially. A male, also from Bogota, differs from the type virtually only sexually.

\section{Genus EPIMECOIDEUS Ashmead}

Epimecoideus Ashmead, Proc. U. S. Nat. Mus., vol. 23, p. 52, 1900. (Genotype, E. apicalis Ashmead, monobasic.)

I have already discussed this genus, ${ }^{3}$ indicating its close relationship and possible synonymy with Neotheronia Krieger, while Townes ${ }^{4}$ goes even farther and synonymizes both Epimecoideus and Neotheronia with Theronia Holmgren.

EPIMECOIDEUS APICALIS Ashmead

Female.-Length $14 \mathrm{~mm}$., antenna $13 \mathrm{~mm}$., sheath $3 \mathrm{~mm}$.

Very slender; body entirely polished and unsculptured.

Head thin, temples nearly flat and very strongly sloping; malar space very short.

3 Proc. U. S. Nat. Mus., vol. 58, p. 44, 1920.

${ }^{4}$ Ann. Ent. Soc. Amer., vol. 23, p. 289, 1940. 
Thorax rather strongly compressed; notaulices deep but very short; scutellum low, margined to middle; propodeum with very strong apical carina but without trace of basal carina; wings broad; legs relatively long and slender, hind femur nearly reaching apex of abdomen. Abdomen very slender, tergite 1 four times as long as broad at apex and with sides nearly parallel, tergite 2 more than twice as long as broad at base; ovipositor and sheath slender.

Entirely bright ferruginous except for black antennae, hind tarsus, apex of middle tarsus, and the sheath; wings brassy hyaline with brilliant reflections, front wing broadly infumate apically, hind wing narrowly so.

Type locality.-Ecuador.

Type.-U.S.N.M. No. 22171.

A single female.

\section{Genus ZONOPIMPLA Ashmead}

Zonopimpla Ashmead, Proc. U. S. Nat. Mus., vol. 23, p. 55, 1900. (Genotype, $Z$. albicincta Ashmead, monobasic.)

The only specimen bearing the name label "Zonopimpla albicincta Ashm." is from Peru, not Africa as indicated in the original description. It agrees with the description in all but the metathoracic character of the second couplet under 11 . The statement "metathorax areolated" should read metathorax not areolated, for in neither of the genera to which it applies is the propodeum at all areolated.

The type of the genotype lacks the head and the prothorax. It is a polished, unsculptured, and highly ornamented Epiurus, representative of an apparently rather large group in the Neotropical region. The group bears the same relation to the Holarctic section of Epiurus as does the Neotropical section of Calliephialtes to the Holarctic section. It exhibits much the same variation in abdominal, tarsal, and ovipositor structure as that of the Holarctic section.

Enderlein's proposed genotype of Zonopimpla, Z. ashmeadi Enderlein, appears to be a Calliephialtes on account of the long ovipositor. Many species of Calliephialtes, including the genotype, have the second tergite in the female no longer than broad, which is the only character in Ashmead's key separating Zonopimpla and Calliephialtes.

(Zonopimpla Ashmead $)=$ Epiurus Foerster. New synonymy.

(Zonopimpla Enderlein, not Ashmead, genotype Z. ashmeadi Enderlein $=$ Calliephialtes Ashmean. New synonymy.

(Zonopimpla ashmeadi Enderlein) =Calliephialtes ashmeadi (Enderlein). New combination. 


\section{EPIURUS ALBICINCTUS (Ashmead), new combination}

Zonopimpla albicincta Ashmead, Proc. U. S. Nat. Mus., vol. 23, p. 55, 1900.

Female.-Length (estimated) $8 \mathrm{~mm}$., ovipositor sheath $4 \mathrm{~mm}$.

Entire body polished and unsculptured and sparsely hairy.

Head and prothorax missing.

Thorax rather elongate, sutures and foveae shallow; legs rather stout, especially the tarsi, the apical joints of which are broadly depressed with stout, sharply bent claws.

Abdomen elongate fusiform; carinae of tergite 1 obsolete; tergites 2-5 with impressions deep and tubercles prominent; ovipositor slender, subsagittate at apex, sheath with fine, short hair.

Thorax ferruginous; metapleuron and propodeum black and white, the white apical and lateral on propodeum and dorsal on metapleuron; middle leg luteous, femur with a brown streak dorsally, tibia dorsally and tarsus blackish; hind leg black, coxa dorsally and ventrally and trochanter white; wings hyaline, venation dark; abdomen black, each tergite broadly margined apically and laterally with white, tergites $2-6$ with black spots on apical margins near lateral angles; sheath black.

Type locality.-Pinches and Perene Vs., Peru, 2,000-3,000 ft.

Type.-U. S. N. M. No. 56286.

One specimen received from the Geographical Society of Lima.

\section{Genus ERYTHROPIMPLA Ashmead}

The type specimen of the genotype is in the collection of the National Museum. It is badly broken, but most of the broken-off parts are glued to a card, so the specimen is still complete except for the antennae and the ovipositor sheath.

This genus, together with the Australian Camptotypus Kriechbaumer and the Oriental Trichiothecus Cameron, have been synonymized with the Ethiopian Hemipimpla Saussure. The first three are doubtless synonymous, Camptotypus having priority, but, judging from the few species available to me, Hemipimpla may be distinct. The conspicuously fasciate wings of Hemipimpla together with the shorter ovipositor give a quite different impression from that of Camptotypus with its yellow, black, or apically black wings and longer ovipositor. In addition, Hemipimpla has the malar space shorter, the ocelli larger, the notaulices deeper with prescutum more convex, the dorsal carinae of tergite 1 much weaker and that segment more densely sculptured, the basal abscissa of radius virtually as long as the apical abscissa, and the long sides of the areolet parallel, whereas the opposite of each of these characteristics usually pertains in Camptotypus. I therefore prefer to use Camptotypus for the Oriental and Australian species and restrict Hemipimpla to the Ethiopian species. 


\section{Genus CAMPTOTYPUS Kriechbaumer}

Camptotypus Kriechbaumer, Ent. Nachr., vol. 15, p. 311, 1889. (Genotype,

C. sellatus Kriechbaumer, monobasic.)

Erythropimpla Ashmead, Proc. U. S. Nat. Mus., vol. 23, p. 57, 1900. (Genotype, E. abbottii Ashmead, monobasic.)

Trichiothecus Cameron, Journ. Straits Branch Roy. Asiatic Soc., vol. 39, p. 138, 1903. (Genotype, T. ruficeps Cameron, monobasic.)

\section{CAMPTOTYPUS ABBOTTII (Ashmead), new combination}

Erythropimpla abbottii Ashmead, Proc. U. S. Nat. Mus., vol. 23, p. 57, 1900.

Female.-Length $19 \mathrm{~mm}$., ovipostor sheath broken but probably about $15 \mathrm{~mm}$.

Head and thorax polished and virtually unsculptured; head in front view transversely subtriangular; face slightly narrower than frons, weakly impressed on each side of middle; clypeus nearly flat; semicircularly emarginate; malar space two-thirds as long as basal width of mandible; temples flat, narrow, strongly receding; diameter of lateral ocellus hardly as long as postocellar line; occipital carina obsolescent.

Thorax deeper than broad; epomia absent; notaulices very weak; prepectoral carina obsolescent; mesopleural furrow and fovea virtually wanting; scutellar frenum unsculptured, postscutellar frenum very weakly foveolate; furrows and carinae separating propodeum and upper and lower divisions of metapleuron entirely effaced, propodeum with scattered, shallow punctures. Legs rather stout and short; apical tarsal joints very broad, depressed, claws large, sharply bent, basal teeth large. Wings broad; apical abscissa of radius distinctly longer than basal abscissa and forming a rather strongly sigmoid curve; areolet nearly twice as long as broad, narrowed toward apex; intercubitella long, strongly oblique and strongly recurved at upper end, the two abscissae of radiella equal; nervellus broken at nearly a right angle at about lower third.

Abdomen broader than thorax, with deep furrows setting off strongly convex median areas and tumid apical margins; first tergite nearly without sculpture, dorsal carinae very strong, especially at summit; tergites $2-5$ with furrows foveolate and each with a median, triangular, coarsely punctate area; tergite 6 without furrows and more finally and extensively punctate; last two tergites polished.

Ferruginous with only flagellum and ovipositor sheath black; wings yellowish hyaline with faintly infumate apical margins.

Type locality.-Trong, Lower Siam.

Type.-U. S. N. M. No. 56290.

The type was taken by Dr. W. L. Abbott. A second specimen, only $12 \mathrm{~mm}$. in length, is labeled "Peninsula Siam, Nakon Sri Tamarat, Khad Ram, 1200 ft." It was taken Feb. 26, 1922, by H. M. Pendlebury. 
The genotypes of the following genera have been described subsequent to their original publication, identified by synonymy with other species, or have not been found:

\section{Genus CHROMOCRYPTUS Ashmead}

Chromocryptus Ashmead, Proc. U. S. Nat. Mus., vol. 23, p. 41, 1900. (Genotype, C. albopictus Ashmead.)

I have already ${ }^{5}$ published a description and the synonymy of this genus and of its genotype ${ }^{6}$ and synonymized the genotype with Chromocryptus planosae (Fitch).

\section{Genus NEOPIMPLA Ashmead}

Neopimpla Ashmead, Proc. U. S. Nat. Mus., vol. 23, p. 56, 1900. (Genotype, N. abbottii Ashmead.)

I have been unable to find the type or any other specimen of this species.

\section{Genus LEPTOBATOPSIS Ashmead}

Leptobatopsis Ashmead, Proc. U. S. Nat. Mus., vol. 23, p. 47, 1900. (Genotype, L. australiensis Ashmead.)

I have already discussed this genus ${ }^{7}$ and later ${ }^{8}$ synonymized the genotype with Leptobatopsis indicus (Cameron) and have given the synonymy of the genus.

\section{Genus EUCTENOPUS Ashmead}

Euctenopus Ashmead, Proc. U. S. Nat. Mus., vol. 23, p. 50, 1900. (Genotype, $[E$. zealandicus Ashmead $]=E$. novazealandicus Ashmead.)

It should be noted that the first publication of this genus was in the Proceedings of the Linnaean Society of New South Wales, which is dated June 27, 1900, whereas the Classification of the Ichneumon Flies did not appear until October 13, 1900. Also, the genotype was originally described as $E$. novazealandicus. The genus is very closely allied to Phytodietus, from which it differs, in addition to the venational characters given by Ashmead, in its lack of the prepectoral carina and its more distinctly defined notaulices. The malar space is not effaced, as stated by Ashmead, but is fully a third as long as the basal width of the mandible.

\footnotetext{
${ }^{5}$ Proc. U. S. Nat. Mus., vol. 58, p. 254, 1920.

${ }^{6}$ Jour. Washington Acad. Sci., vol. 15, p. 389, 1925.

7 Philippine Journ. Sci., vol. 20, p. 591, 1922.

${ }^{8}$ Ins. Matsumurana, vol. 8, p. 17, 1933.
} 


\section{Genus TREVORIA Ashmead}

Trevoria Ashmead, Proc. U. S. Nat. Mus., vol. 23, p. 50, 1900. (Genotype,

T. yukatatensis [sic] yakutatensis Ashmead.)

The genotype was later described by Ashmead ${ }^{9}$ himself. It is represented only by the type male from Yakutat, Alaska. The misspelling of the specific name, which led Dalla Torre to record the species as from Yucatan, was corrected in the second reference. The genus appears to be most closely related to Cryptopimpla Taschenberg, differing principally in the lack of the apical carina of the propodeum. The pentagonal areolet is only an exaggeration of a condition that sometimes occurs in Cryptopimpla.

\section{Genus PIMPLOPTERUS Ashmead}

Pimplopterus Ashmead, Proc. U. S. Nat. Mus., vol. 23, p. 52, $1900 . \quad$ (Genotype, $P$. alaskensis Ashmead.)

The genotype was redescribed by Ashmead. ${ }^{10}$ It is a Lissonota very closely allied to, and perhaps synonymous with, frigida (Cresson), the most obvious difference being the largely black trochanters of alaskensis.

(Pimplopterus Ashmead $)=$ Lissonota Gravenhorst. New synonymy.

(Pimplopterus alaskensis Ashmead) =Lissonota alaskensis (Ashmead). New combination.

The above new combination renders Lissonota alaskensis Ashmead (1902) a secondary homonym, which is disposed of as follows:

(Lissonota alaskensis Ashmead, 1902, not [Pimplopterus] Lissonota alaskensis [Ashmead], 1900) =Lissonota sakala, new name.

\section{Genus HARRIMANIELLA Ashmead}

Harrimaniella Ashmead, Proc. U. S. Nat. Mus., vol. 23, p. 52, 1900. (Genotype, H. yukakensis [sic] kukakensis Ashmead.)

The genotype was redescribed by Ashmead ${ }^{11}$ with the spelling of the specific name, derived from the type locality, Kukak Bay, Alaska, corrected.

In my opinion the genus is not distinct from Lissonota.

(Harrimaniella Ashmead)=Lissonota Gravenhorst. New synonymy.

(Harrimaniella kukakensis Ashmead $)=$ Lissonota kukakensis Ashmead. New combination.

\footnotetext{
${ }^{9}$ Proc. Washington Acad. Sci., vol. 4, p. 196, 1902.

${ }^{10}$ Idem.

11 Ibid., p. 198.
} 


\section{Genus ALLOTHERONIA Ashmead}

Allotheronia Ashmead, Proc. U. S. Nat. Mus., vol. 23, p. 55, 1900 . (Genotype, A. 12-guttata Ashmead.)

Townes ${ }^{12}$ has synonymized the genus with Echthromorpha Holmgren and the genotype with $E$. intricatoria (Fabricius).

\section{Genus GLYPTOGASTRA Ashmead}

Glyptogastra Ashmead, Proc. U. S. Nat. Mus., vol. 23, p. 57, 1900. (Genotype, G. hawaiiensis Ashmead.)

Ashmead later ${ }^{13}$ gave a formal description of the genotype; and Townes ${ }^{14}$ has synonymized the genus with Echthromorpha Holmgren.

\section{Genus POLYSPHINCTOMORPHA Ashmead}

Polysphinctomorpha Ashmead, Proc. U. S. Nat. Mus., vol. 23, p. 59, 1900. (Genotype, P. luggeri Ashmead.)

I have transferred this genus to the subtribe Thymaridina, synonymized it with Netiopisthus Thomson, and redescribed the type species. $^{15}$

\section{Genus PLEURONEUROPHION Ashmead}

Pleuroneurophion Ashmead, Proc. U. S. Nat. Mus., vol. 23, p. 86, $1900 . \quad$ (Genotype, P. hawaiiensis Ashmead.)

Ashmead redescribed and figured the genotype in Fauna Hawaiiensis, vol. 1, pt. 3, p. 342, pl. 9, fig. 1, 1901.

\section{Genus ATHYREODON Ashmead}

Athyreodon Ashmead, Proc. U. S. Nat. Mus., vol. 23, p. 87, 1900. (Genotype, A. thoracicus Ashmead.)

Hooker ${ }^{16}$ has recharacterized the genus and synonymized the genotype with Athyreodon atriventris (Cresson). He failed, however, to indicate the type locality, Ecuador, or to include it in the distribution of the species.

\section{Genus BANCHOGASTRA Ashmead}

Banchogastra Ashmead, Proc. U. S. Nat. Mus., vol. 23, p. 87, 1900. (Genotype, B. nigra Ashmead.)

Ashmead ${ }^{17}$ redescribed and figured the genotype.

\footnotetext{
12 Ann. Ent. Soc. Amer., vol. 33, p. 288, footnote, 1940.

${ }^{13}$ Fauna Hawaiiensis, vol. 1, pt. 3, p. 338, 1901.

14 Ann. Ent. Soc. Amer., vol. 33, p. 288, footnote, 1940.

${ }^{15}$ Proc. U. S. Nat. Mus., vol. 56, pp. 378, 380, 1919.

${ }_{10}$ Trans. Amer. Ent. Soc., vol. 38, pp. 100, 102, 1912.

${ }^{17}$ Fauna Hawaiiensis, vol. 1, pt. 3, p. 343, pl. 9, fig. 3, 1901.
} 


\section{Genus PYCNOPHION Ashmead}

Pycnophion Ashmead, Proc. U. S. Nat. Mus., vol. 23, p. 87, 1900. (Genotype, P. molokaiensis Ashmead.)

Ashmead ${ }^{18}$ redescribed and figured the genotype.

\section{Genus OPHELTOIDEUS Ashmead}

Opheltoideus Ashmead, Proc. U. S. Nat. Mus., vol. 23, p. 95, 1900. (Genotype, O. johnsoni Ashmead.)

No specimen of the genotype has ever been found, but Bradley ${ }^{19}$ synonymized the genus with Parabates Foerster. Townes ${ }^{20}$ suggests a possible relationship of the genotype to Hadrodactylus longicornis (Cresson). The generic description is entirely inadequate as a basis for any speculation as to its identity.

18 Ibid., p. 343 , pl. 9 , fig. 3 .

19 Ann. Mag. Nat. Hist., ser. 9, vol. 3, p. 324, 1919.

${ }^{20}$ Lloydia, vol. 1, p. $173,1938$. 


\section{$2 \mathrm{BHL}$ Biodiversity Heritage Library}

Cushman, R. A. 1942. "The genotypes of some of Ashmead's genera of Ichneumon-flies." Proceedings of the United States National Museum 92, 277-289.

View This Item Online: https://www.biodiversitylibrary.org/item/53694

Permalink: https://www.biodiversitylibrary.org/partpdf/52751

\section{Holding Institution}

Smithsonian Libraries

\section{Sponsored by}

Smithsonian

\section{Copyright \& Reuse}

Copyright Status: Public domain. The BHL considers that this work is no longer under copyright protection.

This document was created from content at the Biodiversity Heritage Library, the world's largest open access digital library for biodiversity literature and archives. Visit BHL at https://www.biodiversitylibrary.org. 